\title{
KOŚCIÓL PARAFIALNY POD WEZWANIEM \\ ŚW. STANISŁAWA BISKUPA I MĘCZENNIKA W LIGOCIE BIALSKIEJ (DIECEZJA OPOLSKA)
}

W ramach obchodów 750. rocznicy kanonizacji krakowskiego biskupa pragnę niniejszym krótkim słowem włączyć się w jubileuszowe spojrzenie na fenomen trwałości kultu tego Świętego Patrona na terenie Śląska Opolskiego. Rozważanie tzw. sprawy św. Stanisława jest zajmujące ze względu na włączenie się w rozważania z wielkiej historii. Natomiast ciągle czeka na szerokie potraktowanie szybko rozwijający się już w średniowieczu kult tego Patrona. Jest to aktualne szczególnie żywo w odniesieniu do Śląska, bowiem religijna cześć dla Patrona Polski była na tej ziemi bardzo wyraźnie zauważalna. J. Rajman zebrał okruchy kultu przedkanonizacyjnego ${ }^{1}, \mathrm{ks}$. W. Schenk zajął się Jego kultem w świetle ksiagg liturgicznych ${ }^{2}$, ks. K. Dola pieczołowicie zebrał świadectwa tego kultu z przejawami żywotności tradycji polskich na Śląsku ${ }^{3}$. Całościowe jednak objęcie tego zagadnienia jest jeszcze ciągle bardziej postulatem badawczym, niż pozostającą do dyspozycji synteza. W niniejszym krótkim szkicu pragnę zwrócić uwagę na jeden z elementów, składających się na trwałość obecności św. Stanisława w świadomości Śląska Opolskiego, a którym jest sięgający swym powstaniem co najmniej XIV w. kościół parafialny w małej wiosce na terenie ziemi prudnickiej, $w$ dawnym, jeszcze średniowiecznym archidiakonacie opolskim.

Parafia Ligota Bialska należy do starszych na terenie obecnej diecezji opolskiej. Wioska nie leży na żadnym wielkim szlaku handlowym czy komunika-

\footnotetext{
${ }^{1}$ Przedkanonizacyjny kult św. Stanisława Biskupa, „Nasza Przeszłośc”” 80 (1993), s. 5-49.

${ }^{2}$ Kult liturgiczny św. Stanisława Biskupa na Slasku w świetle średniowiecznych rękopisów liturgicznych, Lublin 1959.

${ }^{3}$ Kult św. Stanisława biskupa i męczennika a tradycje polskie na Slasku, „Studia Teologiczno-Historyczne Śląska Opolskiego" 7 (1979), s. 245-260.
} 
cyjnym, zawsze egzystowała w cieniu równie dawnego miasteczka Biała (niemiecka nazwa: Zülz). Sama miejscowość wymieniona została po raz pierwszy 14 I 1376 r. w rejestrze przygotowanym przez kardynała Jana, biskupa Sabiny, na potrzeby kurii papieskiej w Awinionie; jako wieś kościelna wyliczona została $w$ ramach wspomnianego już dekanatu Biała ${ }^{4}$. Następnie wioska wspomniana została $w$ dokumencie $\mathrm{z} 1383 \mathrm{r}$, a to $\mathrm{z}$ racji wspomnienia o niej jako przynależnej do książęcego działu głogóweckiego po podziale księstwa opolskiego przez Władysława Opolczyka ${ }^{5}$. Nade wszystko parafia wyliczona jest w zestawieniu rachunków świętopietrza z 1447 r. dla całego archidiakonatu opolskiego w ramach dekanatu Biała ${ }^{6}$. Musiał więc kościół powstać w tejże wiosce na przełomie XIV i XV w., kiedy cały Śląsk, a także Kościół tej ziemi, przeżywały okres swego rozkwitu. Natomiast niczego bliższego nie dowiadujemy się co do okoliczności i motywów twórców i patronów tego kościoła i genezy jego wezwania, ale z pewnością żywotność tego kultu była tutaj wiodącą siłą duchowa, by temu akurat kościołowi nadać to wezwanie.

Element katolicki na tej ziemi musiał być silny, skoro już po zamieszkach związanych z reformacją przetrwał, a parafię Ligota pod wezwaniem krakowskiego Świętego, z zaznaczeniem, że wszyscy mieszkańcy są katolikami, wylicza biskup wrocławski Sebastian Ignacy v. Rostock w $1667 \mathrm{r}$. w swej relacji ad limina Apostolorum do Rzymu? . Natomiast dopiero pierwsze szersze wiadomości o kościele posiadamy z końca XVII w., a to dzięki zachowanym protokołom z dwóch wizytacji, przeprowadzonych w tymże dekanacie w 1679 i 1687 r. $\mathrm{Z}$ obu wynika jasno, że w Ligocie był kościół parafialny, murowany, $\mathrm{z}$ ołtarzem głównym św. Stanisława; w pierwszym $\mathrm{z}$ tych protokołów zanotowano, że kościół był konsekrowany, w drugim wiadomości w tym względzie już nie były

${ }^{4}$ Podaje tę informację J. H e y n e, Dokumentirte Geschichte des Bisthums und Hochstiftes Breslau, Bd. 2, Breslau 1864, s. 121. Przytacza ją H. T u k a y, Oberschlesien im Spannungsfeld zwischen Deutschland, Polen und Böhmen-Mähren. Eine Untersuchung der Kirchenpatrozinien im mittelalterlichen Archidiakonat Oppeln, Köln-Wien 1976, s. 201.

${ }^{5}$ Przytacza go H. N e u 1 in g, Schlesiens Kirchorte und ihre kirchlichen Stiftungen bis zum Ausgange des Mittelalters, Breslau 1902 s. 54.

${ }^{6}$ Rejestr ten zamieszcza H. M a r k g r a f, Die Rechnung über den Peterspfennig im Archidiakonat Oppeln, „Zeitschrift des Vereins für Geschichte und Alterthums Schlesiens” Bd. 27 (1893), s. 379, oraz L. S c h u l t e, Die Rechnung über den Peterspfennig von 1447. Studien über die deutsche Besiedlung und die Parochialverfassung Oberschlesiens, „Darstellungen und Quellen zur schlesischen Geschichte" Bd. 23 (1918), s. 35. B. P a n z r a m, Geschichtliche Grundlagen der ältesten schlesischen Pfarrorganisation, Breslau 1940, s. 123, nr 1265. Na te przekazy powołuje się ks. W. S c h e n k, dz. cyt., s. 28.

${ }^{7}$ In archipresbyteratu Cilcensi: „,(..) In pago Elgott ecclesia parochialis sub titulo S. Stanislai, parochiani catholici...", por. Wykaz kościołów diecezji wroctawskiej z 1667 r., oprac. i wydał J. Kopiec, „Archiwa, Biblioteki i Muzea Kościelne” t. 55 (1987), s. 188. 
pełne $^{8}$. Nawet te mnikome informacje są jednak ważnym nośnikiem trwałości kultu naszego Świętego mimo oderwania od jedności państwowej z ziemiami polskimi, długiej przynależności do monarchii Habsburgów oraz dramatycznych wydarzeń reformacyjnych.

Warto uzmysłowić sobie dodatkowo, że do początków XX w. językiem kazań i nauczania religii był w tej parafii język polski. Każdego roku odpust w niedziele po 8 maja ściaggał do Ligoty thumy wiernych, pragnących zamanifestować swój narodowy charakter polski. Podtrzymywano także więź z Krakowem poprzez wyjazdy do tego miasta. Przy okazji, nawet pobieżna analiza ksiag chrzcielnych, zachowanych w parafii od 1789 r., wskazuje, że imię Stanisław było obecne w parafii, nawet nieco częściej nadawano to imię chłopcom urodzonym $w$ maju w filii $w$ Radostyni. Czy można $z$ tego wyciągać jakiś wniosek o szczególnym kulcie Świętego Patrona - chyba nie, poza stwierdzeniem, że jako Patron był on obecny i ten fakt był dla mieszkańców czymś zupełnie naturalnym.

Do naszych czasów nie zachował się pierwotny kościól, pamiętający przełom średniowiecza i wiek XVI. Na początku XX stulecia okazał się być już niewystarczającym dla wzrastającej liczby parafian - w 1891 r. było w parafii 2050 katolików - $\mathrm{i}$ do tego wymagającym niemal natychmiast poważnych remontów, nade wszystko $\mathrm{z}$ uwagi na zawilgocenie. Budowy więc nowego kościoła podjął się proboszcz parafii Ligota w latach 1896-1921 ks. Aleksander Skowroński, znany działacz narodowy polski na Śląsku Opolskim?.

Już w 1890 r. na posiedzeniu Rady parafialnej pojawił się postulat budowania nowej świątyni ${ }^{10}$. Długo trwały zabiegi o uzyskanie pozwolenia na budowę nowej świątyni, dyskutowano o wielkości zamierzonej świątyni i jej nowej lokalizacji, sporo też czasu zajęło gromadzenie potrzebnych na budowę funduszy. Ostatecznie kościół został wybudowany w latach 1908-1909. Dnia

${ }^{8}$ W 1679 r.: „Parochialis ecclesia in villa Lgotta illustrissimi domini comitis Pruskowsky, in honorem s. Stanislai extructa et consecrata", por. Visitationsberichte der Diözese Breslau, hrgs. J. Jungnitz, B. 2, Breslau 1904, s. 180; w 1688 r.: „In pago Ellgoth est ecclesia parochialis, de cuius consecratione ignoratur, erecta sub titulo s. Stanislai episcopi et confessoris, dedicatio seu memoria erectionis celebratur dominica prima post festun omnium Sanctorum (...) Altare maius sine cancellis formale s. Stanislai, cum ara limata non consecrata", tamze, s. 543-544. Interesującym może być fakt, że kościół nie posiadał relikwii św. Stanisława, jak np. mógł się nimi poszczycić kościól parafialny w Chrząszczycach koło Opola, gdzie „reliquiae s. Stanislai habentur in pacificali, in statua una lignea et in manu lignea" - Visitationsberichte, s. 298.

${ }^{9}$ Jego obszerny biogram opublikował E. S z ra m e k, Ks. Aleksander Skowroński. Obraz życia i pracy na tle problematyki kresów zachodnich, „Roczniki Towarzystwa Przyjaciół Nauk na Slasku" t. 5 (1936), s. 37-38.

${ }^{10}$ G. T y r a ła, Dzieje parafii Swiętego Stanistawa Biskupa i Męczennika w Ligocie Bialskiej (diecezja opolska), Nysa 1991 (mps pracy magisterskiej); o budowie kościoła s. 103-111. Stary kościół rozebrano dopiero w 1923 r. 
29 VI 1908 r. ks. A. Skowroński poświęcił kamień węgielny, 31 V 1909 r. nowe dzwony do kościoła, zaś 15 XI 1909 r. poświęcenia gotowej już świątyni dokonał dziekan dekanatu bialskiego ks. Fryderyk v. Woyski z Lacznika. Uwieńczeniem wszystkich starań była uroczysta konsekracja, której dopełnił biskup pomocniczy z Wrocławia Karol Augustyn 16 VI 1912 r. Nowy kościół otrzymał wezwanie poprzedniej świątyni, czyli św. Stanisława Biskupa i Męczennika.

W ten sposób powstał nowy kościół, murowany $z$ cegły i ciosanych kamieni w stylu neogotyckim, trójnawowy z transeptem, będący dziełem architekta Ludwika Schneidera z Wrocławia; robotami budowlanymi kierował budowniczy Heda, miejscowy doświadczony rzemieślnik, główny ołtarz rzeźbiony był w Nysie, a malowidła wykonał - według pomysłu ks. Skowrońskiego R. Richter z Kłodzka.

Jak podkreślają wszyscy znawcy, prawdziwym klejnotem kościoła są trzy witraże w absydzie, wykonane w Düsseldorfie według kartonów Włodzimierza Tetmajera (1861-1923), przyrodniego brata Kazimierza, znanego malarza i grafika ${ }^{11}$. Uczeń m.in. Jana Matejki potrafił łączyć wpływy impresjonizmu, motywy ludowe i secesyjną dekoracyjność. Nie sposób dotrzeć do inspiracji pomysłu, dlaczego ks. Skowroński zwrócił się właśnie do W. Tetmajera z prośba o wykonanie tak prestiżowego zadania. Prawdopodobnie sława artysty skierowała zasłużonego proboszcza bialskiego właśnie do niego. Do dziś witraże są zachowane i świadczą o kunszcie artystycznym i ideowym programie. Środkowy, centralny witraż przedstawia św. Stanisława, wywołującego Piotrowina z grobu, prawy - apostołów Słowian św. Cyryla i Metodego na tle krajobrazu ze stara lipą słowiańską i drewnianym kościółkiem, a lewy - nawiązuje do rozmowy św. Pawła z Piotrem na temat przymuszania do judaizmu (na podstawie Listu do Galatów 2, 14). W tym programie artystycznym została zawarta głęboka idea o konieczności pracy narodowej na pogranicznym terenie, którym był rejon Prudnika. Wszystkie witraże zawierały głęboką myśl: troska o postawę patriotyczna, jak św. Paweł, historyczny głos o słowiańskim udziale w życiu Kościoła oraz św. Stanisław, z podniesionymi jak prorok rękami i wskrzeszający Piotrowina - wypełnia swoje zadanie wobec ludu śląskiego, poddanego szczególnej presji elementu niemieckiego. Nie ulega wạtpliwości, że tym dziełem ks. A. Skowroński odnowił żywotność myśli i kultu św. Stanisława Biskupa, a przez zamówienie dzieła tak wysokiej klasy przyczynił się do wzbogacenia także ikonografii Świętego Patrona Polski. Kartony W. Tetmajera, ujęte w tryptyk, pozostały w Ligocie, stanowiąc tło sedilii po prawej stronie, prowadzącej do zakrystii.

${ }^{11}$ Zob. jego biogram w: Encyklopedia Krakowa, Warszawa-Kraków 2000, s. 996. Więcej na temat jego kunsztu por. J. A. Now o bilski, Sakralne malarstwo ścienne Wtodzimierza Tetmajera, Kraków 1994 - o Ligocie Bialskiej s. $101 \mathrm{n}$. 


\section{Parish Church Dedicated to St. Stanislaus, Bishop and Martyr at Ligota Bialska (Diocese of Opole) \\ Summary}

This note constitutes a contribution to the history of worship of St. Stanislaus, Bishop and Martyr, in the Opole are of Silesia, where this worship has been strong since the Middle Ages. Taking as an example the dedication of a parish church at Ligota Bialska (German Ellguth) to St. Stanislaus, it wants to show the permanence of the reverence for this Saint. The fact that a new church, built in the years 1908-1909 in the place of the old one (which dated back to the Middle Ages) received the same invocation is yet another proof. Stained-glass windows designed by a Cracovian painter W. Tetmajer are a beautiful decoration of this church. 